821.134.2(862)-31.09 Маркес Г. Г.

https://doi.org/10.18485/kud_kp.2018.ch12

\author{
проф. др Весна Дицков \\ Универзитет у Београду \\ Филолошки факултет \\ vesna.dickov@fil.bg.ac.rs
}

\title{
КРИТИЧКИ ОДЈЕК НАРАТИВНЕ ПРОЗЕ ГАБРИЈЕЛА ГАРСИЈА МАРКЕСА У СРПСКИМ КЮИЖЕВНИМ ЧАСОПИСИМА ${ }^{1}$
}

\section{Сажетак}

Објављивање (1973) превода романа Сйо йоgина самоће (Cien años de soledad) на српском језику, побудило је велико интересовање не само за опусом Габријела Гарсија Маркеса, већ и за књижевношћу Латинске Америке, а пре свега за новом хиспаноамеричком прозом, који су стекли велику популарност, како међу широм читалачком публиком, тако и у професионалним круговима. Сврха овог рада је да, из хронолошке перспективе, представи однос српске критике у књижевним часописима (кроз разне есеје, критичке чланке и студије) према Гарсија Маркесовим прозним делима (романима, причама); настојаћемо да истакнемо главне елементе (учеснике, еволуцију критике) овог интерпретативног аспекта пријема (без анализирања приказа), а на крају ћемо покушати да одредимо његов утицај на формирање хоризонта очекивања читалаца у Србији.

Кључне речи: хиспаноамеричка књижевност, Габријел Гарсија Маркес, магични реализам, рецепција, српска књижевна критика.

1 Овај рад је објављен 2014. године на шпанском језику под насловом "La crítica de la obra narrativa de Gabriel García Márquez: en las revistas literarias serbias" у часопису Verba Hispánica (no. XXII: pp. 91-104) који издаје Филозофски факултет Универзитета у Љубљани. 
Први српски критичар који је скренуо пажњу читалачке публике на прозна дела Габријела Гарсија Маркеса, био је Владета Кошутић, који је у есеју „Тај божанствени Маркес“ (Кошутић 1975) истакао значај романа $C \bar{u} о$ іоgина самоће у оквиру светске књижевности. Кошутић упоређује Гарсија Маркесових Сӣо іодина самоће са

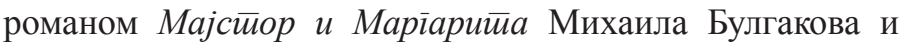
долази до спознаје да ова два дела - због њиховог сличног начина суочавања са темом самоће и магије, фабуле, слојевите имагинације и приповедачког поступка - представљају нову полазну тачку у развоју савремене прозе у свету. Међутим, магија у Сӣо їоgина самоће, за разлику

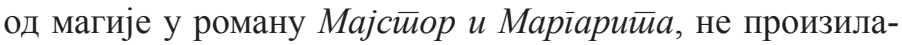
зи из паклених сила, већ је реч о хиперболичним чудима судбине, са лирском конотацијом, који су самостално настали и дискретни су у својој манифестацији, те омогућавају природно стапање са реалношћу, обогаћујући је циљаном симболиком, која је латентна, испуњена тугом, трагедијом или страстима (Кошутић 1975: 4). Анализа романа $C \bar{u} о$ їоgина самоће започиње са критичким освртом Марија Варгас Љосе (датим у његовој књизи Габријел Гарсија Маркес: истиорија јеgноі боїоуисиива [Gabriel García Márquez: historia de un deicidio]), према којем се аутор поставља у роману као Творац, односно, противник Бога и ствара свој властити имагинарни свет, људе, време и димензије које сматра одговарајућим, инспирисан различитим књижевним изворима (Фокнер, Хемингвеј, Дефо, Борхес, Хиљьаgу и јеgна ноћ, Ками, Конрад, Вирџинија Вулф), као и сећањима из детињства. Главна тема усамљености, која изазива вишеструка чуда, одражава усамљен, ћутљив и лутајући људски дух, те упућује на подтему самоће мртвих. Кошутић сматра да је у Гарсија Маркесовом делу романтична тема преминулих који су сиромашни и усамљени (толико честа код Бодлера, Верлена, Бекера, Унамуна и Милоша) комплекснија, јер мртви саосећају са живима. Са друге стране, политичке 
и друштвене околности у данашњој Латинској Америци нуде још један неисцрпан извор на који се Гарсија Маркес често позива на сатиричан начин, тако да његов реализам изненада постаје надреализам "sans riem en lui qui pèse ou qui pose" (Кошутић 1975: 4). Такође се коментарише начин разраде теме усамљености у роману Пуковнику нема ко gа йише (El coronel no tiene quien le escriba) и наглашава се да се у овом делу ради о самоћи својственој искључиво једној професији, те да је реч о протагонисти који је представљен са мешавином пародије, трагикомедије и многих лирских елемената у процесу изолације и напуштања било каквог односа са људском расом. Овај кратак роман омогућава српском критичару да успостави низ релација: Гарсија Маркес се повезује са Јонеском или Арабалом, док је пуковник сродан Мојсију Алфреда де Вињија. На крају, закључује се да роман Пуковнику нема ко gа йише, са својом ограниченом самоћом, није достигао уметничке вредности ни тренутни успех романа $C \bar{u} о$ іоgина самоће, ремек-дела које је одмах привукло публику оркестрираном самоћом Буендијевих (Кошутић 1975: 5).

Компаративни приступ такође одликује и текст Србе Игњатовића „Маркес, између Борхеса и Гарсије Калдерона“ (Игњатовић 1977) у којем се разлози за спектакуларан успех романа $C \bar{u} о$ їoguна самоће траже у приповедачком поступку и обрађеним темама. У том циљу, Игњатовић пореди Гарсија Маркесове књижевне изворе са изворима Хорхеа Луиса Борхеса, Мигела Анхела Астуријаса и Вентуре Гарсија Калдерона, односно, са оним хиспаноамеричким писцима који су у то време већ били добро познати у Србији захваљујући преведеним делима и који су се често опредељивали за теме митолошко-легендарне природе. Слично Борхесу, Гарсија Маркес тематизује „интелектуалне слагалице“, али за разлику од Борхеса, који посредством слагалица ствара уметничку, фокусирану и независну реалност, Гарсија Маркес растаче тако створену реалност користећи шалу, парадокс, хумор и иронију, 
све у циљу омогућавања поновног успостављања њихове фиктивне стварности у библијској пројекцији (,, од 100 година“) и у оквиру хронике. Астуријасови романи обухватају одређене политичке и друштвене ситуације из глобалне перспективе, док Гарсија Маркес представља догађаје у низу секвенци чија виталност замењује конзистентност у целини (Игњатовић 1977: 14-15). Од аутора наведених у наслову есеја, Гарсија Маркес је најудаљенији од Гарсија Калдерона, који, уместо да интерпретира митске теме, тежи да непосредно створи легендарне ситуације, без икаквих спекулативних књижевних трансформација. Стога, Гарсија Маркес, према речима Србе Игњатовић, представља синтезу традиционалних и модерних књижевних тема, проседеа и ресурса (Игњатовић 1977: 16).

Синтетички карактер хиспаноамеричке књижевности и утицај европског супстрата, посебно шпанског, наглашава Кринка Видаковић у есеју „Габријел Гарсија Маркес: фантастика и техника“" (Видаковић 1977). Француска, са својим надреалистима, утицала је у великој мери на уобличавање Астуријасове наративне прозе, као и на прихватање интелектуалне и апстрактне фантастике код Борхеca, док је утицај Кафке очигледан у Гарсија Маркесовој антологији Очи йлавої йca (Ojos de perro azul), а Фокнера у његовом кратком роману Oхараска (La hojarasca) (Видаковић 1977: 428-429). Ауторка посвећује (као Владета Кошутић) посебну пажњу теми усамљености у прозним делима Габријела Гарсија Маркеса, али сматра да у ње-

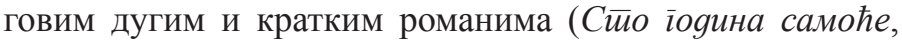
Пуковнику нема ко gа йише, Зао час [La mala hora]) и причама (Сахрана велике маме [Los funerales de la Mamá Grande]) није присутна лирска обрада самоће, већ да се пре ради о самоћи са политичким импликацијама (нешто што се никада не дешава у борхесовој прози). У том смислу, критички поглед Кринке Видаковић се надовезује на претходно поменуто мишљење Владете Кошутића, јер разматра егоцентричну усамљеност, која у политичком 
контексту представља нездраву жељу за влашћу, жељу која лежи иза свих свакодневних политичких фарси, које стварају искривљену слику стварности и која се, на крају, трансформише у фантастичну маску прикривајући трагичну стварност људског живота (Видаковић 1977: 430).

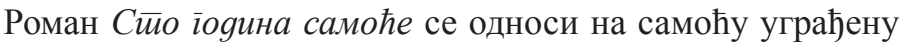
у људску судбину и сви ликови су на неки начин невероватни, јер су им врлине и мане или пренаглашене или превише потиснуте; Гарсија Маркес се поиграва са књижевношћу (као Сервантес) и уноси елементе фантастичног и митског да би разбио прозаичност свакодневног живота. Међутим, у случају романа Јесен йайријарха (El otoño del patriarca) аутор се налази иза маске, управо да би разоткрио монструозни унутрашњи свет патријарха, затамниченог у сопственој егоцентричној самоћи, или другим речима - како каже Кринка Видаковић - са овом врстом наративног поступка, пуног метафора, који почиње од реализма и завршава са симболизмом, Гарсија Маркес се поново враћа техници експерименталног романа (Видаковић 1977: 432-433).

Када је седамдесетих година прошлог века «бум» хиспаноамеричке књижевности постао термин познат на српском језичком подручју, Бранко Анђић се у чланку „Abracadabra marquesiana“ (Анђић 1978) критички осврнуо на улогу Гарсија Маркеса у појави овог феномена код Срба и указао на велики раскорак међу преводима који је постојао у то време у Србији у погледу хиспаноамеричке књижевности: док је потражња за Гарсија Маркесовим књигама била непрекидна, дела других врхунских хиспаноамеричких писаца (Хуан Рулфо, Алехо Карпентјер, Карлос Фуентес, Марио Варгас Љоса) су пролазила готово незапажено, а дела његових наследника - већ признатих аутора (Салвадор Елисондо, Гиљермо Кабрера Инфанте, Северо Сардуј, Агустин Јањес, Данијел Мојано), практично су остала непозната. По мишљењу Бранка Анђића, све ово је било последица тога што су српски 
читаоци сматрали да их је спознаја Гарсија Маркесовог чаробног реализма приближила хиспаноамеричкој савременој књижевности уопште. Међутим, поједини неквалитетни преводи довели су до засићености тржишта у погледу Гарсија Маркесових књига, за шта је најочигледнији пример наслов кратког романа La hojarasca који је погрешно преведен као Охараска, што за српске читаоце значи исто што и „абракадабра“ (Анђић 1978: 3).

Потом, Бранко Анђић пише у критици ,Час антике у карипском селу“ (Анђић 1981) о Гарсија Маркесовом роману Хроника најављене смриии (Crónica de una muerte anunciada), непосредно пре његовог објављивања на српском језику. Анђић анализира поменуто дело (тема апсурдног убиства, структура мозаичног карактера, изражајна средства - пародија, хипербола, иронија -, снови, легенде, цртице из свакодневног живота) да би приказао Гарсија Маркесову приповедачку вештину која долази до изражаја приликом комбиновања хиспаноамеричке традиције (дихотомија село-град, фигура мушкарца) са античким наслеђем (трагедија и њена способност да подари универзално значење локалним догађајима). Узрочни ланац догађаја остаје као такав да постоји само у структури романа, без гарантовања обавезне вероватноће; напротив, читалац је присиљен да прихвати фаталан и неприхватљив стицај околности да би препознао неопходну равнотежу коју захтева космичка правда и вредности претходно представљене у збирци приповедака Сахрана велике маме (Анђић 1981: 21). Крајња последица читања романа Хроника најављене смрйи за Бранка Анђића је осећај празнине и апсурда који стварају апокрифни људски односи у којима нема никаквог моралног оправдања нити покрића.

Тумачење кратког романа Пуковнику нема ко gа йие које даје Мирољуб Јоковић у тексту „Фрустрирана стварност“ (Јоковић 1978), односи се на одлике које су, по мишљењу аутора, од пресудног значаја за формирање 
мозаичне структуре овог Гарсија Маркесовог дела, чија је главна идеја да прикаже потпуну ерозију људских вредности, распадање које обухвата све: од брачног језгра до колектива. Прво, Јоковић наглашава значај снова који служе пуковнику као последњи одбрамбени механизам његовог идентитета против еродиране стварности, а, затим, анализира улогу петла као предмета фрустрације како на плану комуникације јунака са његовим жена, тако и на плану представљања заједнице у којој петао постаје нека врста ироничне дистанце коју пуковник одржава у односу на људе који га окружују. Сместивши радњу овог дела у јесен, Гарсија Маркес симболично указује на мрачну визију живота у целости (Јоковић 1978: 5). Имајући у виду да се акција делимично одвија линеарно и да ликови повремено нису изграђени са одговарајућим психолошким интензитетом, Мирољуб Јоковић претпоставља да наклоност коју je са̂м Гарсија Маркес гајио према поменутом роману у поређењу са другим његовим делима, проистиче из личних пишчевих разлога, а не из уметничких вредности дела као што би се могло помислити у првом тренутку.

Критички одјек који се развио током седамдесетих година прошлог века у српским књижевним часописима обухвата и чланак Милана Влајчића „Маркесова магија“ (Влајчић 1978) у којем су представљене главне одлике магичног реализма Габријела Гарсија Маркеса на основу анализе двају његових прозних творевина. Пре свега, Влајчић нас подсећа да је аутор романа Сйо іоgина самоће постао веома популаран у Србији након објављивања овог дела, чему у прилог наводи тираже првих издања поменуте књиге на српском и шпанском језику, као и континуирано присуство овог романа на светском књижевном тржишту, те говори о његовим карактеристикама (теми, поступку својственијем усменој књижевности, омиљеним изражајним средствима и језику) због којих ово дело, у ствари, представља синтезу поезије, хумора и пародије. Друга књига која је побудила Влајчићево интересовање 
је збирка прича Неверовайна и иижна исиоорија невине Ерендире и њене безяушне бабе (La increíble y triste historia de la cándida Eréndira y de su abuela desalmada); анализа седам приповедака, које чине ову компилацију, показује да је Гарсија Маркесов стил исти као и у роману $C \bar{u} о$ īogина самоће - магичан, виртуозан, примамљив; иако се радње прича дешавају на различитим местима и обично се премештају на Карипска острва, аутор је и даље инспирисан митским светом Маконда, те користи претеривања сродна народним приповедачима (иронија, пародија, фарса, хумор), као и елементе својствене надреализму и фантастичном жанру да би изразио вечну људску чежњу за лепим и недостижним (Влајчић 1978: 627-628).

Темом жена у хиспаноамеричкој књижевности бави се Весна Ристић у обимној студији под насловом „Љу-

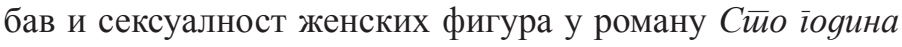
самоће» (Ристић 2007a, Ристић 2007б), која се састоји од два дела: а) први део (Ристић 2007а: 126-132) садржи, у светлу самоће као главне идеје и љубави као доминантног осећања, детаљну анализу психолошког грађења и минуциозну типологију следећих женских ликова из поменутог дела: Урсула Игуаран (Úrsula Iguarán) (централна лич-

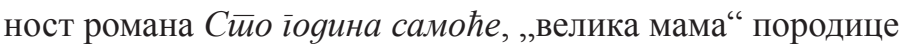
Буендија, створена по угледу на најважнију жену [и идол] у пишчевом животу - његову баку Транкилину Игуаран Кортес [Tranquilina Iguarán Cortés]), Пилар Тернера (Pilar Ternera) (алтруистички, можда једини лик у роману који је ослобођен у старости патње изазване самоћом), Амаранта (Amaranta) и Ребека Буендија (Rebeca Buendía) (два женска лика која су прво уједињена будући да је реч о сестрама и пријатељицама, а касније постају непосредно супротстављена због љубавних збивања), Фернанда дел Карпио (Fernanda del Carpio) (најнегативнија, најмрачнији и најусамљенији женски лик у роману) и Петра Котес (Petra Cotés) (други алтруиста, али на другачији начин у односу на Пилар; најхуманији и најплеменитији лик у 
Сӣо іоgина самоће); б) други део (Ристић 2007б: 120-126) је посвећен тумачењу наративног поступка и изражајних средстава којима се користио Гарсија Маркес да би извр-

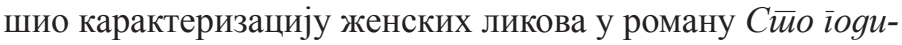
на самоће и одредио њихову специфичну сексуалност. Умножавањем имена (три жене се зову Ремедиос [Remedios]) се указује на сличности њихових судбина (ниједна од трију Ремедиос није доживела зрелост јер су умирале или нестајале веома младе); способност да постоји само у датом тренутку наглашава секундарну улогу женског лика (на пример, такав је случај Аркадијеве [Arcadio] жене Санта Софије де ла Пиједад [Santa Sofía de la Piedad]); мирис са афродизијачким ефектом се користи као одлучујући елемент физичке привлачности (Пилар Тернера). Сексуалност је једна од основних особина скоро сваког лика у роману који је пун сцена експлицитних сексуалних односа. Женски ликови се деле на оне који имају позитивну сексуалност (Урсула, Санта Софија де ла Пиједад), са здравим односом према сексу у оквиру концепта љубави и породице, као и на ликове који имају негативну сексуалност (Амаранта, Фернанда дел Карпио) који, у ствари, потискују своју сексуалност. Друга класификација коју је сачинила Весна Ристић разликује јунакиње са наглашеном сексуалношћу (Пилар Тернера, Амаранта Урсула [Amaranta Úrsula]) од готово асексуалних жена (Ремедиoc Москоте [Remedios Moscote]). Сексуалност у роману Сйо іооина самоће има и негативне конотације: инцест као производ изолације и самоће (Амаранта, делимично Ребека, посебно - Амаранта Урсула) и силовање изазвано фаталном лепотом и сексуалношћу женских ликова (Урсула, Амаранта Урсула). У закључку, дата је оригинална визија романа $C \bar{u} о$ іо gина самоће као великог женског романа; истиче се да женски ликови имају значајну предност у односу на мушке ликове јер представљају стабилну базу и налазе се у средишту свих догађаја (Ристић 2007б: 127). Ауторка студије тврди да су сви женски ликови суочени 
са породицом и домом или са еротским односима, тако да љубав и сексуалност, односно чињеница да ли поседују или не ове особине, одређује њихову судбину. Стога, порука романа Сйо іолина самоће несумњиво, за Весну Ристић, гласи да само љубав и брига за друге могу спасити модерну цивилизацију од себичности и отуђења.

Интересовање да осветли Гарсија Маркесову прозу са генолошке тачке гледишта, Радомир В. Ивановић је испољио у различитим радовима. Студију „Краћи приповедни облици у прози Г. Г. Маркеса“ (Ивановић 2010а), започиње са прегледом неколиких општих, савремених дефиниција кратких и дугих прозних врста, да би их потом применио у сопственој анализи Гарсија Маркесових приповедака. Актуелност, аутентичност и постојаност интересовања читалаца су главне карактеристике кратких наративних форми Габријела Гарсија Маркеса, које представљају спој документарне прозе и фикције. Његовим причама, често заснованим на анегдотама или народној традицији, недостају епизоде и процес развоја радње, jep је сва пишчева пажња усмерена на драматичну тензију и притисак контекста, што ове творевине често приближава поетској прози, а, понекад, још више ритмичкој прози (Ивановић 2010а: 83-84). Аутор студије инсистира на параметрима Гарсија Маркесових кратких прозних врста (флуидно окружење, функционална непотпуност средишне радње и њена екстремна краткоћа) који су у великој мери допринели афирмацији његове прозе уопште. Најрепрезентативнија приповетка младог Гарсија Маркеса, по Ивановићу, јесте прича Горчина за ири месечара (Amargura para tres sonámbulos) у којој се обрађују три теме - сенка, усамљеност и евокација - са великим економичношћу у употреби стилских средстава; наративна потка је смештена у интеракцији живота и смрти, то јест, у односу рационалног и ирационалног страха од живота, а профил главне јунакиње, затворене у свету безизлазне депресије, сведочи о дубоким психолошким спознајама 
аутора и његовој способности да проникне у домен подсвесног. Гарсија Маркесов магични реализам открива, такође, пишчеву способност да представи како невероватне догађаје тако и оне који су могући и истинити; шири се регистар тема и мотива у његовој прози, и богати се спектар примењених приповедачких поступака, што се, по мишљењу Ивановића, најбоље види у причама Неко реметии ове руже (Alguien desordena esas rosas), Ноћ букавия (La noche de los alcaravanes), Вешитачке руже (Las rosas artificiales) и Свейлосии је као воgа (La luz es como el agua) (Ивановић 2010а: 87-88).

У другој студији „Повест као потврда даровитости“ (Ивановић 2010б), Радомир Ивановић тврди да је дело Пуковнику нема ко gа иичие приповетка, а не роман, због очигледног недостатка многих карактеристика композиционе схеме романа, тј. „одсутне структуре“. Ивановић наглашава да се модернитет интимне исповести насловљене Пуковнику нема ко gа ииише испољава на естетском, поетском и креативном плану, те да се огледа у краткоћи њене епске форме, економичној употреби изражајних средстава и избегавању одређених поступака (снажна литераризација и поетизација историје; одсуство решења које би проистицало из сфере очекивања писца и читалаца; одсуство привидног инсистирања на процесу саосећања које се развија између епских субјеката и реципијената). Анализира се Гарсија Маркесова способност да исприча једну стару причу, која је актуелна у сваком културном моделу, на веома поједностављен начин и да изгради ликове на основу бинарних опозиција користећи иронију, сарказам, гротеску и хумор (Ивановић 2010б: 47-48). Српски критичар открива нивое наративне структуре (дословне податке, мање опипљиве чињенице које карактеришу изненадни окрети, невидљиве податке који захтевају изненадна открића, ретроспекције историјске или породичне прошлости) које Гарсија Маркес користи за описивање механизма насиља на којем се заснивао друштвени си- 
стем у Колумбији у првим деценијама 20. века. На крају, закључује да се писац намерно одрекао употребе различитих стилова, тако да се прећутна значења или „одсутни садржаји“ могу схватити као „додатна рекапитулација приче“ која се реализује кроз сарадњу са примаоцем, почев од његовог саосећања са протагонистом - пуковником (Ивановић 2010б: 51).

Анализу Гарсија Маркесове поетике кроз алтернативну интерпретацију његових књига Живеии gа би се ирийовеgало (Vivir para contarla) и Риба је црвена (El pez es rojo), Радомир Ивановић даје у студији „Таленат покреће свет“ (Ивановић 2010в) која се састоји од три дела: а) „Идеографска кореспонденција“ - пружа преглед најновијих открића у литературологији, посебно у области наратологије и генологије, истичући Гарсија Маркесову идеју о „хибридизацији култура“, ,хибридизацији језика“ и „хибридизација жанрова“, која се сублимира у идеји о мешању стваралачких поступака и њиховој међусобној коресподенцији, где је „воља жанра“ често супериорнија од „воље аутора“(Ивановић 2010в: 271); б) „Наративно-скриптивна кореспонденција“ - открива главне обрисе Гарсија Маркесове креативне метаморфозе у којој пресудну улогу има дар оригиналности или аутентичности виђења и елаборирања уочених, измишљених или наслућених истина (Ивановић 2010в: 273); в) „Међужанровска коресподенција“ - показује доминацију теорије накнадних интервенција у односу на теорију спонтаности у Гарсија Маркесовом креативном процесу, јер су реверзибилна читања његових приповедака и романа показала да аутор поклања пажњу интенционалној фази настајања дела (инкубација инспирације може да траје више година), затим фази самокритике сопственог дела (избором низа варијаната приче) и на крају, критички проверава примењене креативне поступке и ригорозно вреднује остварене естетске домете (Ивановић 2010в: 281).

Милан Балинда је написао чланак „Габо између ко- 
рица“" (Балинда 2011) са намером, исказаном у уводној напомени, да представи најзначајнија дела Габријела Гарсија Маркеса по редоследу објављивања њихових првих издања на шпанском језику. Стога, чланак се састоји од коментара (19) Гарсија Маркесових дела (романа, приповедака, репортажа, мемоара, новинарских чланака, говора) која су штампана у раздобљу дужем од педесет година (1955-2010). Премда Балинда није испољавао научне претензије књижевно-теоријског типа, чланак нуди не само занимљиве и недовољно познате информације о Гарсија Маркесовим књигама (када и како су написане, друштвене и приватне - везане за писца и његову породицу - околности у којима су настале; тиражи првих издања и њихове судбине, као и потоњи успех и преводи; добијене књижевне награде, или филмови који су снимљени на основу Гарсија Маркесових дела), већ и критичку оцену (компаративно сагледавање неколиких Гарсија Маркесових дела, порекло и генеза различитих верзија неких његових књига, теме, садржаји, кратке анализе ликова, извори, стилске карактеристике, Гарсија Маркесове евалуације сопственог дела, мишљења књижевне критике) изложену на концизан и веома сугестиван начин.

Студија Миле Медиговић-Стефановић „Текст је тајна треперења стварности и снова“ (Медиговић-Стефановић 2011) садржи два дела: а) критички приказ (Медиговић-Стефановић 2011: 20-23) монографије Лавиринии чаробної реализма Габријела Гарсије Маркеса (Подгорица, 2011) Радомира В. Ивановића у којој аутор покушава да реконструише наративни систем Габријела Гарсија Маркеса на основу наратолошких и генолошких анализа, као и сопствених интерпретативних и критичких искустава, бавећи се такође појединим теоријским питањима (разлика између магичног реализма, чаробног реализма и фантастичног реализма; писци који су пресудно утицали на Гарсија Маркесово књижевно формирање); б) елаборација (Медиговић-Стефановић 2011: 23-27) неких тема 
својствених Гарсија Маркесовој прози (Макондо као хронотоп, према Ивановићу и Бахтиновој теорији; позитивни и негативни утицаји на избор наратолошких догађаја; самоћа; љубав и смрт; Ерос; диктатура).

Компаративна студија Дамјана Стевкића „Концепција историје и схватање прошлости у роману Вилијама Фокнера Авесаломе, Авесаломе! и Габријела Гарсије Мар-

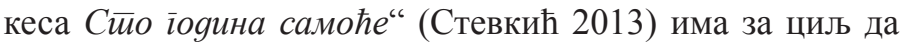
идентификује разлике и сличности између књижевних поступака код оба писаца и састоји се од шест делова: a) „Утицај Вилијама Фокнера на хиспаноамеричке писце“ - Фокнеров начин приказивања регионалне маргинализације и економске изолације подударао се са тежњом многих хиспаноамеричких писаца да опишу своју борбу за независност од шпанског јарма и постигну друштвену и економску еманципацију (Стевкић 2013: 73); б) „Степен утицаја Вилијама Фокнера на стваралаштво Г. Г. Маркеса“ - захваљујући сличним књижевним и културолошким околностима, те упркос многим разликама (животне доби, државе у којима су рођени, приватни животи, политичка ангажованост) утицај Фокнера на Гарсија Маркеса је био веома јак и трајан (Стевкић 2013: 74); в),Авесаломе, Авесаломе! и Сйо їоgина самоће“" - приказивање фрагментарне стварности кроз различите перспективе, без икаквог хронолошког редоследа, својствено Фокнеровој прози, оставило је дубок траг на Гарсија Маркеса приликом писања Сйо їоgина самоће (Стевкић 2013: 75); г) „Концепција историје и инцестоидна осећања код В. Фокнера и Г. Г. Маркеса“" - оба аутора посматрају прошлост као саставни део садашњости и будућности у спиралном протоку времена, те да се проблем инцеста може разматрати заједно са питањем мешања раса (Стевкић 2013: 77-9); д) „Слабљења времена у Авесаломе, Авесаломе!“ - Фокнерови, као и Гарсија Маркесови ликови пате од усамљености, имају инцестоидна осећања и сличне карактерне особине које се понављају у свим генерацијама и чврсто одређују 
њихове животе унутар круга који је настао још у далекој прошлости (Стевкић 2013: 80); Ђ), ,Третирање прошлости у Сйо їоgина самоће“ - наративно време је кружног облика, а прошлост већ припада будућности; Гарсија Маркес, као Фокнер, ствара митско време које се супротставља конвенционалном, линеарном времену (Стевкић 2013: 81-82).

На крају овог рада може се закључити да критички одјек наративне прозе Габријела Гарсија Маркеса, који се развио у српским књижевним часописима у другој половини 20. века и почетком 21. века (1975-2013), обухвата најзначајније аспекте везане за прозу поменутог хиспаноамеричког писца (извори, теме, структуре, ликови, поступци, стилска изражајна средства). Ова врста књижевне критике очигледно је варирала по интензитету током четири истражене деценије, одржавајући све време висок ниво објективности и расуђивања, који су били засновани на модерним књижевним теоријама и научним дисциплинама као што су наратологија, генологија и упоредна књижевност. Половина написаних текстова изашла је у београдским часописима, а највише (4) прилога је објављено у часопису Кьижевна реч. У истраженом периоду, најплоднији аутори били су Радомир Ивановић и Бранко Анђић. Иако су се у својим текстовима углавном усредсређивали на роман Сйо їоgина самоће, српски критичари су анализирали и друга Гарсија Маркесова прозна дела, остављајући и даље низ могућности за будућа проучавања која би, надамо се, могла да буду изведена на организованији начин него досадашња.

Литература:

Анђић, Бранко. „Abracadabra marquesiana“. Кюижевна реч 108 (1978): 3. Штампано.

Анђић, Бранко. „Час антике у карипском селу“. Књижевна реч 176 (1981): 21. Штампано. 
Балинда, Милан. „Габо између корица. Најзначајнија дела Габријела Гарсије Маркеса сврстана по редоследу првих издања на шпанском језику“. Савременик йлус 192/193/194 (2011): 42-54. Штампано.

Vidaković, Krinka. „Gabrijel Garsija Markes: fantastika i tehnika“. Savremenik 5 (1977): 427-434. Štampano.

Влајчић, Милан. „Маркесова магија“. Кюижевност̄ LXV/4 (1978): 625-628. Штампано.

Игњатовић, Срба: „Маркес, између Борхеса и Гарсије Калдерона“. Граяина 2 (1977): 14-17. Штампано.

Ивановић, Радомир В. „Краћи приповедни облици у прози Г. Г. Маркеса“. Траі̄ 21 (2010a): 81-92. Штампано.

Ивановић, Радомир В. „Повест као потврда даровитости. Пуковнику нема ко gа пише“. Злайна ірреgа 101/102 (2010б): 46-52. Штампано.

Ивановић, Радомир В. „Таленат покреће свет. Г. Г. Маркес: од аутобиографије до аутопоетике“. Годишъак за срйски језик и кьижевносӣ 10 (2010в): 267-288. Штампано.

Јоковић, Мирољуб. „Фрустрирана стварност“. Кьижевна реч 111 (1978): 5. Штампано.

Кошутић, Владета. „Тај божанствени Маркес“. Кюижевна реч 46 (1975): 4-5. Штампано.

Медиговић-Стефановић, Мила. „Текст је тајна треперења стварности и снова“. Кровови 79/80 (2011): 20-27. Штампано.

Ристић, Весна., „Љубав и сексуалност женских фигура у роману Сйо йоgина самоће (I)“. Свеске 83 (2007a): 125-133. Штампано.

Ристић, Весна. „Љубав и сексуалност женских фигура у роману Сйо йоgина самоће (II)““. Свеске 84 (2007б): 120-129. Штампано.

Стевкић, Дамјан. „Концепција историје и схватање прошлости у роману Вилијема Фокнера Авесаломе, Авесаломе! и Габријела Гарсија Маркеса С̄̄o йоgина самоће“. Поља 484 (2013): 73-82. Штампано. 


\section{Prof. Vesna Dickov, PhD \\ University of Belgrade \\ Faculty of Philology}

\section{LA CRÍTICA DE LA OBRA NARRATIVA DE GABRIEL GARCÍA MÁRQUEZ EN LAS REVISTAS LITERARIAS SERBIAS}

\section{Resumen}

Desde la aparición (1973) de la traducción de la novela Cien años de soledad, la obra narrativa de Gabriel García Márquez no deja de despertar el interés de los críticos serbios. Tras la lectura de la obra por los lectores, la interpretación del realismo mágico de García Márquez y otros aspectos de su prosa empezó a desarrollarse muy pronto en Serbia (a partir del año 1975), y se intensificó en los años setenta del siglo pasado y al final de la primera década del siglo XXI, cuando se publicó una serie de ensayos, críticas, artículos y estudios sobre las novelas, los cuentos, los reportajes, los ensayos y las memorias de García Márquez, incluso sobre su obra periodística. La mitad de los textos escritos por los críticos serbios para las publicaciones literarias periódicas, salió en las revistas de Belgrado, sobre todo en la revista Književna reč (La palabra literaria), siendo los autores más prolíficos Radomir Ivanović y Branko Anđić. El juicio de la crítica serbia presentado en las revistas literarias, basado con frecuencia en los últimos avances de la narratología, genealogía y la literatura comparada, ha contribuido en gran medida a la formación del horizonte de expectativas de los lectores, no solamente en cuanto a la obra en prosa de Gabriel García Márquez, sino también por lo que respecta a la nueva narrativa hispanoamericana en general.

Palabras clave: literatura hispanoamericana, Gabriel García Márquez, realismo mágico, recepción, crítica literaria serbia. 